\title{
Xylem water in riparian Willow trees (Salix alba) reveals shallow sources of root water uptake by in situ monitoring of stable water isotopes
}

\author{
Jessica Landgraf ${ }^{1,2}$, Dörthe Tetzlaff ${ }^{1,2,3}$, Maren Dubbert ${ }^{1,4}$, David Dubbert ${ }^{1}$, Aaron Smith $^{1}$, and \\ Chris Soulsby ${ }^{3}$ \\ ${ }^{1}$ Department of Ecohydrology and Biogeochemistry, Leibniz Institute of Freshwater Ecology and Inland Fisheries, \\ Müggelseedamm 310, 12587 Berlin, Germany \\ ${ }^{2}$ Department of Geography, Humboldt-Universität zu Berlin, Rudower Chaussee 16, 12489 Berlin, Germany \\ ${ }^{3}$ Northern Rivers Institute, University of Aberdeen, St. Mary's Building, Kings College, Old Aberdeen, AB24 3UE, UK \\ ${ }^{4}$ Landscape Functioning, Leibniz Centre for Agricultural Landscape Research, Eberswalder Straße 84, 15374 Müncheberg
}

Correspondence: Jessica Landgraf (landgraf@igb-berlin.de)

\begin{abstract}
Root water uptake is an important critical zone process, as plants can tap various water sources and transpire these back into the atmosphere. However, knowledge about the spatial and temporal dynamics of root water uptake and associated water sources at both high temporal resolution (e.g. daily) and over longer time periods (e.g. seasonal) is still limited. We used cavity ring-down spectroscopy (CRDS) for continuous in situ monitoring of stable water isotopes in soil and xylem water for sampling of local precipitation, groundwater and stream water in order to help constrain the potential sources of root water uptake. A local flux tower, together with sap flow monitoring, soil moisture measurements and dendrometry were also used to provide the hydroclimatic and ecohydrological contexts for in situ isotope monitoring. In addition, bulk samples of soil water and xylem water were collected to corroborate the continuous in situ data. The monitoring period was characterised by frequent inputs of precipitation, interspersed by warm dry periods which resulted in variable moisture storage in the upper $20 \mathrm{~cm}$ of the soil profile and dynamic isotope signatures. This variability was greatly damped in $40 \mathrm{~cm}$ and the isotopic composition of the sub-soil and groundwater was relatively stable. The isotopic composition and dynamics of xylem water was very similar to that of the upper soil and analysis using a Bayesian mixing model inferred that overall $\sim 9 \%$ of root water uptake was derived from the upper soil profile. Sap flow and dendrometry data indicated that soil water availability did not seriously limit transpiration during the study period, though there was a suggestion that deeper $(>40 \mathrm{~cm})$ soil water might provide a higher proportion of root water uptake $(\sim 30 \%)$ in a drier period in the late summer. The study demonstrates the utility of prolonged real time monitoring of natural stable isotope abundance in soil-vegetation systems, which has great potential for further understanding of ecohydrological partitioning under changing hydroclimatic conditions.
\end{abstract}




\section{Introduction}

Plants - as the interface between atmospheric and soil water - have an important influence on the water cycle. In terrestrial ecosystems, transpiration from plants accounts for up to $90 \%$ of evapotranspiration (Jasechko et al., 2013) and up to 70\% of incoming precipitation during the growing season (Kozii et al., 2020). Furthermore, vegetation intercepts and redistributes precipitation via canopy evaporation, throughfall and stemflow (Friesen and Van Stan, 2019). Subsequent interactions between soil particles and root water uptake influence soil moisture and soil hydraulic conductivity which in turn affect infiltration and runoff (Thompson et al., 2010). As tree roots take up water, different species can have contrasting preferences in their source water pools (Jackson et al., 1995), while individuals of varying size and age are capable of uptaking water from different soil depths (Kühnhammer et al., 2020). However, root water uptake cannot necessarily be simply correlated with root distribution as it also depends on moisture and nutrient availability at different times of the year (Ehleringer and Dawson, 1992). Consequently, there is still limited knowledge on the temporal dynamics of root water uptake and associated water sources both at high temporal resolution (e.g. daily) and over longer time (e.g. seasonal) periods (Berry et al., 2018; Beyer et al., 2020).

Stable isotopes of water are convenient natural tracers commonly used for the estimation of sources and ages of runoff, (McDonnell et al., 2010; Sprenger et al., 2019), partitioning of evapotranspiration (Williams et al., 2004; Rothfuss et al., 2010; Dubbert et al., 2014), and root water uptake depth distribution (Dawson and Ehleringer, 1991; Goldsmith et al., 2019; Beyer et al., 2018). With the development of compact laser spectrometry systems, in situ monitoring of stable water isotopes in soil and tree xylem is now facilitating higher temporal and spatial resolution assessment to advance well-established destructive sampling methods (Herbstritt et al., 2012; Rothfuss et al., 2013; Volkmann and Weiler, 2014; Oerter and Bowen, 2017). However, destructive sampling followed by cryogenic vacuum extraction, is still widely used for stable water isotope analyses in plants (West et al., 2006; Yang et al., 2015; Orlowski et al., 2016; Sohel et al. 2021) and is usually required to corroborate in situ measurements (see Mennekes et al., 2021). Despite the complexity, daily maintenance and resource demands, the application of in situ methods in different compartments of the critical zone including soil, trees (Kübert et al., 2020; Beyer et al., 2020; Marshall et al., 2020) and the atmospheric-interface (Braden-Behrens et al., 2019) is increasing. Unfortunately, no general, widely-tested setup for such in situ measurements has been established and agreed upon yet (Beyer et al., 2020; Marshall et al., 2020).

Despite limitations, destructive sampling in previous studies revealed important process-based insights into plant-soil water interactions. For example, New Zealand riparian willows were analysed monthly over the course of seven months showing that water sources fluctuated seasonally with root water uptake (RWU) from the near-stream aquifer during summer and from groundwater during winter (Marttila et al., 2017). A labelling experiment of two small willow trees (Salix viminalis) in a lysimeter by Nehemy et al. (2021) also showed RWU to be variable and linked to soil water potential and tree water deficits, shifting deeper as the upper soil dried. in situ monitoring has also revealed other subtleties: sub-daily investigations of xylem water from several tree and shrub species in French Guiana, China and Germany has found morning RWU (when transpiration is low) to be sustained by deeper soil layers, while daytime RWU was concentrated in shallow soil layers (De Deurwaerder et al., 2020). 
For xylem water sampling in particular, destructive methods still dominate the research field. However, it has been shown that the cryogenic extraction method can affect the results due to volatile organic compounds (like alcohols) which can be mixed into the extracted liquid sample (Martín-Gómez et al., 2015) as well as extraction of water held in cell walls (Barbeta et al., 2020). These effects on xylem water samples are only linked to cryogenic extraction and seem absent in in situ experiments. For example, Volkmann et al. (2016) installed a probe horizontally inside the sap wood of a stem borehole to sample xylem water in situ. This method, while delivering a new approach for in situ measurements in plants, showed none of the above mentioned effects but an unexplained ${ }^{18} \mathrm{O}$ offset. Marshall et al. (2020) suggested that this offset might be due to non-equilibrium conditions, leading to their new method of stem borehole equilibration, where the borehole went through the complete stem. This approach was tested to simplify the measuring method and allow for continuous evaporation of liquid xylem water into a flowing airstream that passes the borehole (Marshall et al., 2020). The model description of flow is based on a central core of moving air flow that passes a volume of still air allowing water vapor to diffuse from and to the borehole wall or the moving air stream (Marshall et al., 2020). The method was successful for a cut stem, as well as a live, Scots Pine (Pinus sylvestris) (Marshall et al., 2020). It has not been tested for angiosperms yet.

Despite the advantages, in situ xylem isotope monitoring in the field continues to be rare due to methodological and logistical challenges including root distribution, soil heterogeneities and ambiguous water sources. A recent in situ labelling experiment by Seeger and Weiler (2021) using the same type of stem borehole probes as Volkmann et al. (2016) inside European beech (Fagus sylvatica) trees over the course of 12 weeks found that xylem water differed from actual RWU. This led to the conclusion that xylem water isotopic composition does not necessarily represent simple root water uptake, but rather an integration over certain fractions of root water uptake from different sources in the past (Seeger and Weiler, 2021). They suggested sub-daily monitoring of tree xylem water isotopes might not be suitable to investigate short term RWU dynamics and instead recommended to focus more on spatial heterogeneity in soil and xylem composition (Seeger and Weiler ,2021). Another labelling experiment by Mennekes et al. (2021) investigated plot-scale xylem water isotopes in three different trees of various species (Pinus pinea, Alnus incana and Quercus suber) at two different heights (15 and $150 \mathrm{~cm})$ over the course of 10 weeks using similar tree probes described by Volkmann et al. (2016). They sampled xylem water isotopes at 5-hourly intervals and showed that in situ measurements delivered more consistent results compared to destructive samples.

The integration of high-frequency measurements of water stable isotopes with other plant-physiological variables like sap flux and stem size variation can also increase our understanding of sub-daily and seasonal variations in xylem isotopic composition and improve the comparison of isotope data from different individual plants or trees (De Deurwaerder et al., 2020; Nehemy et al., 2021). Stem size variation is linked to three co-occurring and opposing processes, which are incremental increase (or growth), swelling (from water uptake), and shrinking of the stem (Zweifel, 2016). The latter can be linked to tree water deficit and occurs during imbalances between transpiration and RWU (Zweifel et al., 2005) or differences in osmotic water potentials depending on the sugar content of the phloem (Mencuccini et al., 2013). Sap flow monitoring provides a continuous proxy of transpiration rates (Paloschi et al., 2021). Although usually reflecting the atmospheric vapor pressure deficit (Butz et al., 2018), sap flow rates may react to soil water availability, but these responses are highly species-specific (Brinkmann et al., 2016) and may depend on the distribution of individual water sources, or access to groundwater (Süßel and Brüggemann, 2021). In gen- 
eral, low soil water content combined with high air temperatures may lead to moisture stress resulting in decreased sap flow, lower leaf water potential and turgor, a decline in photosynthesis, stomata closing, reduction in cell enlargement and growth (Joshi et al., 2016).

To identify water sources used by plants from isotopic composition, linear end member-mixing models like IsoSource (Phillips and Gregg, 2003) have been widely used (Barbeta and Penuelas, 2017). More recent approaches with Bayesian frameworks like SIAR (Parnell et al., 2010) or MixSIAR (Stock et al., 2018) also provide statistical uncertainty assessments (Rothfuss and Javaux, 2017). These models are based on the basic assumption that the end members include all potential sources of xylem water and are isotopically distinct (von Freyberg et al., 2020). Furthermore, all end members of a mixture should be identified and uncertainties of the sampling/monitoring method should be taken into account. Recent findings suggest combining Bayesian mixing models with ecohydrological information like soil properties and climate to improve their results (Rothfuss and Javaux, 2017; Kühnhammer et al., 2020). Von Freyberg et al. (2020) stated that in situ monitoring of stable water isotopes with high temporal resolution may help detect isotopic anomalies (like fractionation or new water inputs) and thus, result in more reliable water source attribution.

Here, we used continuous in situ monitoring of the natural abundance of stable water isotopes in soil and xylem water of riparian willow trees (Salix alba) under field conditions over a period of five (soil) and three (trees) months. In order to understand uptake of potential water sources, we compared the isotopic composition of xylem water with soil water as well as precipitation, surface water and groundwater from liquid sampling. We also used destructive bulk soil water and xylem sampling for comparison with in situ measurements. Furthermore, we also monitored soil moisture, sap flow velocity, stem size variation and eddy flux covariance on site. Finally, we used this data in the Bayesian approach mixing model SIAR to calculate the likely distribution water sources used by the trees. Our specific research question was: Can we generate new insights into fluxes across the soil-plant-atmosphere-continuum from combined in situ isotope variation and conventional ecohydrological monitoring (e.g. sap flow, biomass accumulation, soil moisture) to assess water sources tapped by the willow trees?

\section{Study site}

The study site is located in the SE of Berlin, Germany (Fig. 1A). The climate is continental temperate with long-term (1981-2010) mean annual rainfall of $\sim 570 \mathrm{~mm}$ (Deutscher Wetterdienst (DWD), 2020a) and temperature of 9.3-10.0 ${ }^{\circ} \mathrm{C}$ (DWD, 2020a). Berlin is situated in the North European Plain which was formed during the Weichselian glaciation. (Deutsche stratigraphische Kommission, 2016). A glacier tongue stretching from east to west formed a bowl-shaped depression which today contains the largest lake of the city, the Müggelsee at an altitude of $32 \mathrm{~m}$. The lake's inlet and outlet is the river Spree. As a result of groundwater pumping since 1905, lake water can infiltrate into the adjacent groundwater aquifer (Driescher et al., 1993). The upper unconfined aquifer at the Müggelsee consists of sandy and gravel sediments and is underlain by an aquitard of silt and till at about sea level (Driescher et al., 1993).

The Leibniz-Institute of Freshwater Ecology and Inland Fisheries (IGB) is located (Fig. 1A) on the Northern shore of the Müggelsee. In its grounds, an area of roughly $480 \mathrm{~m}^{2}$ was chosen as our study site and focused on two willow trees (Salix 


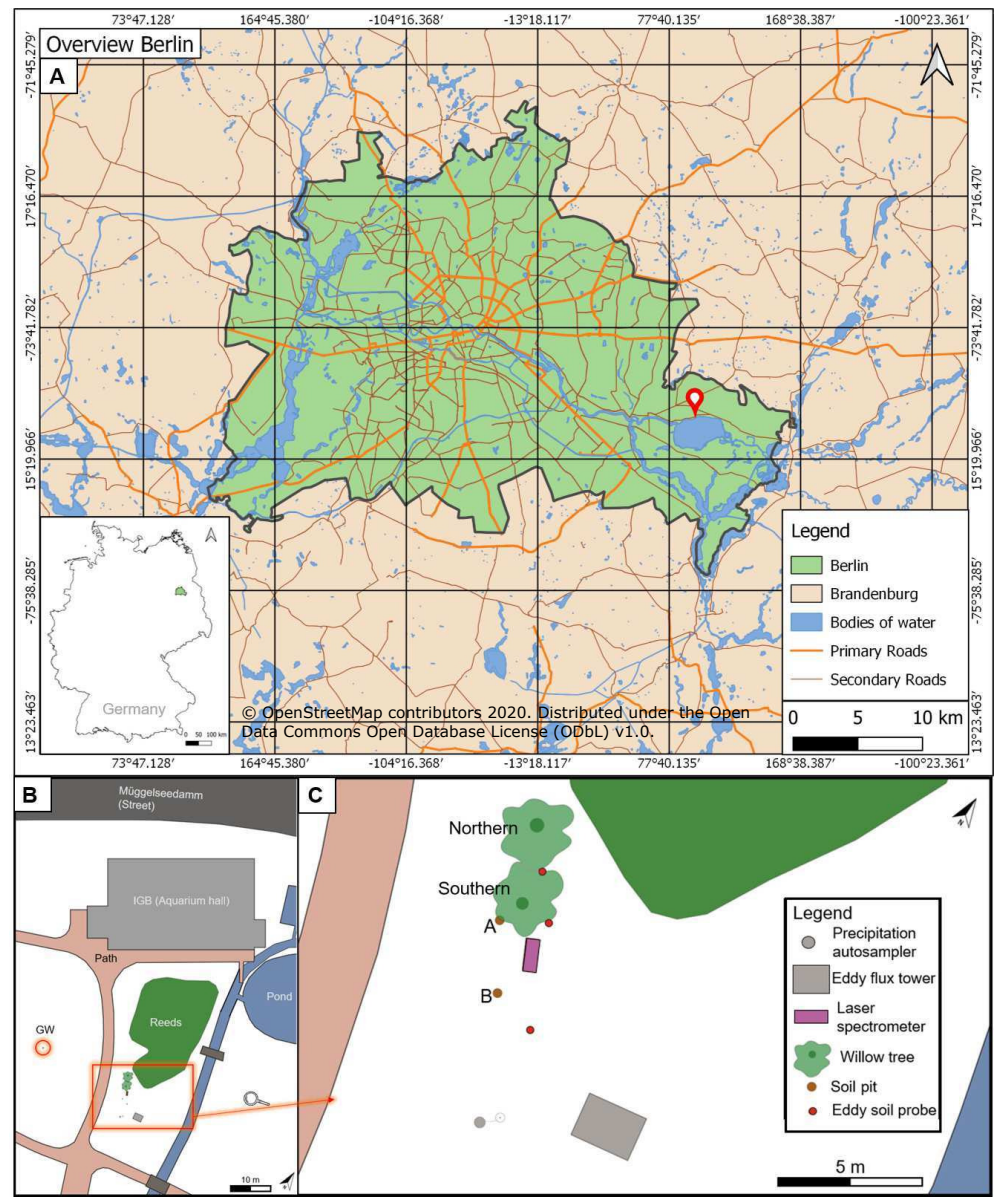

Figure 1. Maps with A) Inner map: Location of Berlin in Germany, Outer map: Overview Berlin with red pin showing the location of the IGB (Map data for map in A: (OOpenStreetMap contributors (2020)), B) Sketch of the study site (highlighted in red rectangle) with GW well (highlighted in red circle), C) Bird's eyes view showing all measuring points.

$a l b a$ ). To the North of the trees is a small wetland and, in the East, a small woodland separated by a small stream (Fig. 1B). The stream is fed by artificial fish ponds which are constantly sustained by pumped lake water. The two willow trees stand relatively isolated and were chosen to replicate the same species and have similar ages (14 years). The northern willow had a stemdiameter of $398 \mathrm{~mm}$ and the southern willow of $353 \mathrm{~mm}$ (16 July 2020). Willow trees were described by Nehemy et al. (2021) as having a fast resource acquisition strategy and are known to have large water demands due to typically high transpiration rates ( 30-100 1/day cf. Schaeffer et al., 2000). Hence, it could be expected that the trees respond rapidly to variations in water availability. In addition, willows are tolerant of waterlogged conditions and can source water from groundwater, so they potentially have flexible strategies of root water uptake depending on soil moisture conditions (Marttila et al., 2017). At our site that also includes the lake-fed stream to the east of the trees. 
In addition to the willows and a few other trees fringing the stream and wetland, the area is covered by grass and moss. There is also a well which we used to monitor groundwater level and isotopes. Lake Müggelsee is roughly $50 \mathrm{~m}$ away from the study site. Despite developing Brown Earth characteristics, the soils comprise relatively homogenous silty sands, with the upper soil layer having a higher organic content. Those soils developed on backfilled ground (following construction work at IGB), which results in the top soil being classified as an Anthrosol (Rossiter, 2007).

\section{Data and methods}

\subsection{Hydroclimatic and hydrometric monitoring}

The study was conducted over most of the growing season in 2020 (from 20 May to 11 October). Climate conditions were monitored using a weather station integrated into a portable Eddy Covariance system (Li-cor Biosciences, Lincoln, NE, USA with LI 7500DS open path analyser; wind measurements via Gill Windmaster pro and a Smart Flux 3 system, frequency 10-20 $\mathrm{Hz}$ (Burba, 2013)) (Fig. 1C). Automatically calculated mean values were logged over 30 min. Measured air temperature, wind (speed and direction), vapor pressure deficit, solar radiation, gas fluxes, precipitation, top soil heat flux, and soil moisture were used in this study. To calculate soil heat flux and moisture, soil water potential was measured with ThetaSondes ML2 (Delta-T Devices, Burwell, Cambridge, UK; accuracy $\pm 2-5 \%$ ) at a depth of $5 \mathrm{~cm}$. The Eddy Flux system automatically calculated evapotranspiration from the latent heat flux (Burba, 2013). In some cases (e.g. power outage) occasional data gaps occurred which were infilled with data from the IGB weather station, ca. $15 \mathrm{~m}$ away at the rooftop of the IGB building. The precipitation data of both stations were compared with the open access precipitation data from the German Weather Service (DWD) of the "Berlin-Marzahn" station (DWD, 2020b).

Soil moisture monitoring took place in two soil pits (Pit A and Pit B) at three depths: 10, 40, and $100 \mathrm{~cm}$. Pit A was located next to the southern willow tree (Southern Willow) and partially covered by its outer branches while Pit B was further south and not covered (Fig. $1 \mathrm{C}$ ). Soil moisture and temperature were measured at the three depths with water content reflectometers CS616 (Campbell Scientific, Inc. Logan, UT USA; accuracy $\pm 2.5 \%$ for volumetric water content (VWC)) and BetaTherm 100K6A1IA Thermistors T107 (Campbell Scientific, Inc. Logan, USA; tolerance $\pm 0.2^{\circ} \mathrm{C}$ (over $0^{\circ}-50^{\circ} \mathrm{C}$ )), respectively with a CR800 Datalogger and Multiplexer (Campbell Scientific, Inc. Logan, USA) logging every 10 min. A delay in completion of Pit A was related to Covid19 lockdowns and resulted in a shorter period of record.

Groundwater levels nearby were monitored with an automatic datalogger (groundwater level probe) at an interval of 15 min (see location in Fig. 1B). For comparison, the groundwater level was also measured manually once a week with a water level meter. The average groundwater level is around $2.2 \mathrm{~m}$ below ground level, and relatively stable with seasonal variations $<10$ $\mathrm{cm}$. 


\subsection{Ecohydrological monitoring}

We continually monitored sap flow and variation in the stem circumference of the willow trees. Sap flow was measured at 15 min intervals using the heat ratio method (Burgess et al., 2001) with four sap flow meters (SFM1 instrument, ICT International, Australia), from which two per tree were installed on the North and South side of the trunk. All sensors were installed at breast height. The measured increase in sapwood temperature following the release of a heat pulse downstream and upstream of the heater is calculated into heat pulse velocity $\left(\mathrm{V}_{\mathrm{h}}\right)$ after Marshall (1958) as

where $k$ is the thermal diffusivity of fresh wood, $x$ is the distance between the heater and either temperature probe, and $v_{l}$ and $v_{2}$ are the increases in temperature at equidistant points downstream and upstream, respectively. Further information on the theory may be found in Burgess et al. (2001).

Variation in stem circumference were observed with two Dendrometers (DR Radius Dendrometer, Ecomatik, Dachau, Germany), one per tree at the northern stem side, at a height of $95 \mathrm{~cm}$ measured from the soil surface. Data were logged at a 15 min interval with a CR300 Datalogger (Campbell Scientific, Inc. Logan, USA).

\subsection{Stable water isotope monitoring}

Stable isotopes of water were monitored in precipitation, groundwater, lake and stream water, bulk soil water, soil water vapor and xylem water vapor. Precipitation water was collected with an autosampler ISCO 3700 (Teledyne Isco, Lincoln, USA) (see Fig. 1C). The autosampler bottles were filled with a paraffin oil layer $>0.5 \mathrm{~cm}$ in thickness (after IAEA/GNIP, 2014) to avoid evaporative effects. Samples were collected at an interval of 4 hours. Lake and stream water samples were collected weekly via grab sampling. A similar interval was used for groundwater, which was accessed with a submersible pump (COMET-Pumpen Systemtechnik GmbH \& Co. KG, Pfaffschwende, Germany). For a period (16 September -14 November 2020) the artificial fish ponds were also sampled as a potential water source for root water uptake. All liquid samples were extracted with a canula equipped syringe, filtered with a cellulose acetate filter $(0.2 \mu \mathrm{m}$ pores $)$ into glass vials and stored in a fridge until analysis. All liquid samples were analysed via CRDS (Picarro L2130-i, Picarro Inc., Santa Clara, CA, USA) at the IGB laboratory.

Destructive sampling of bulk soil water was conducted monthly from June (after the first COVID19 lockdown) to October 2020. Samples were collected at two locations: an open space with grass cover and a 2nd location close to the willow further north (later referred to as Northern Willow). Replicate samples were collected with a hand auger (diameter: $2 \mathrm{~cm}$ ) at 0-10, 10-20, 20-40, 40-70, and 70-100 cm depth. Samples were filled in metalized bags and analysed with the direct-equilibrium method from Wassenaar et al. (2008). Details of sample preparation can be found in Kleine et al. (2020). The samples were equilibrated for roughly $48 \mathrm{~h}$ before analysis. For correction, nine $10 \mathrm{ml}$ standard water samples ${ }^{18} \mathrm{O}(-10.3,-7.68,2.91$ or $1.53 \%$ ) and ${ }^{2} \mathrm{H}(-72.81,-56.70,0.78$ or $16.74 \%$ o) were used during every measuring routine. Soil water vapor analysis from the bags was conducted with a Los Gatos Off-Axis Integrated Cavity Output Spectroscopy (OA-ICOS) triple water-vapor isotope analyser (TWIA-45-EP, Los Gatos Research, Inc., San Jose, CA, USA). In this paper, we will refer to these samples measured with the direct-equilibrium method as "bulk soil water". 


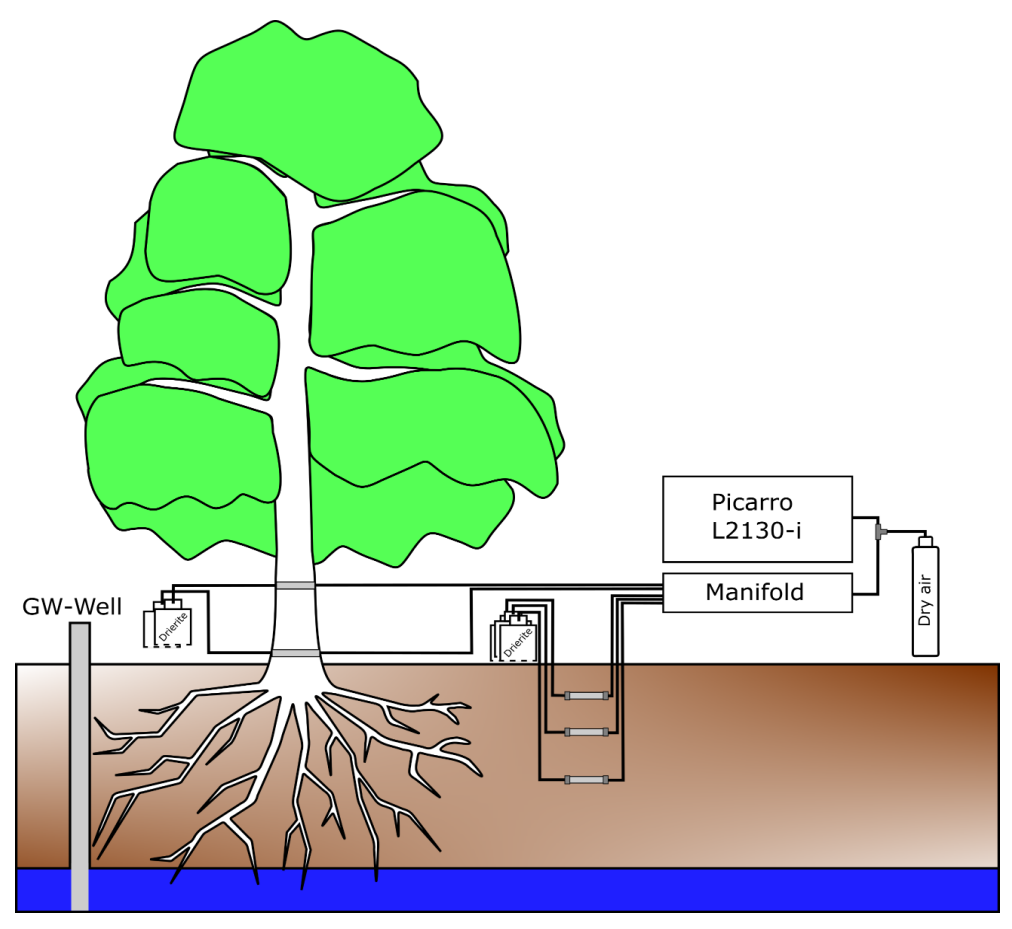

Figure 2. Conceptual graphic of the general in situ isotope measuring setup.

Further, destructive sampling of xylem water was also conducted monthly from July-October 2020 together with the bulk soil water sampling. Each time three sun-exposed branches were collected on Northern and Southern Willow, respectively. Only twigs with intact bark were collected and had their bark and phloem removed to prevent interference. Next, the twigs were cut inside $12 \mathrm{ml}$ vials from Exetainer ${ }^{\odot}$ and immediately sealed with a septum cap. In the field the vials were stored in a polystyrene container and frozen after reaching the lab until cryogenic vacuum extraction. The cryogenic vacuum extraction was done according to Koeniger et al. (2011), but with 60-90 min of extraction time per sample. Before the extraction an empty vial is frozen with liquid nitrogen and evacuated by a vacuum pump. Next, the sample is frozen and connected to the evacuated vial via a stainless-steel capillary tube (Koeniger et al., 2011). Afterwards, to extract the water, the sample vial was placed in a $105^{\circ} \mathrm{C}$ heated custom-built isolated aluminium block (Gaj et al., 2016). After extraction the xylem water samples were measured using CRDS (Picarro L2130-i). We will further refer to the xylem water extracted by cryogenic vacuum extraction as "cryo-xylem water".

Stable water isotopes in soil water vapor were monitored via CRDS (Picarro L2130-i) in the two soil pits (Pit A and Pit B) at the three depths (Fig. 2). For vapor extraction in the soil, $7 \mathrm{~cm}$ long polypropylene membranes $(0.2 \mu \mathrm{m}$ pores) (Kübert et al., 2020) were used. In this paper, we will refer to the samples of the in situ soil pits as "in situ soil water".

Xylem water vapor was monitored with the same vapor sampling device from the two willows (Northern and Southern Willow) inside two stem boreholes each (Fig. 2). Xylem sampling was also delayed due to restrictions resulting from Covid-19 lockdowns. Consequently, measurements of Southern Willow started at 22 June 2020 and Northern Willow at 10 July 2020. At 
the beginning of the monitoring, both willows showed wounding effects resulting in unrealistically high isotopic compositions declining exponentially over time. Hence, these time periods were excluded from further analysis. The boreholes were at $30 \mathrm{~cm}$ (further referred to as "lower") and $170 \mathrm{~cm}$ (referred to as "upper") height above the soil surface. As in the soil, polypropylene membranes were inserted into the boreholes passing the stem horizontally (stem borehole equilibration). We will refer to all xylem water samples by this method as "in situ xylem water". The method of stem borehole equilibration was only tested before on tree logs and in a greenhouse experiment on gymnosperms and resembles a new design of in situ xylem water vapor extraction as tested and suggested by Marshall et al. (2020). In their method, the carrier gas was provided from one end while an extraction tube of an isotope ratio infrared spectrometer (IRIS) for suction was set on the other side of the borehole allowing for linear flow and equilibrium conditions (Marshall et al., 2020). Volkmann et al. (2016) already used microporous polypropylene membranes. Their probe was embedded inside the sap wood and sealed for the inner and outer end of the borehole to prevent contamination with air water vapor (Volkmann et al., 2016). Inside a mixing chamber of the probe, a gas-water-mixture was sucked out by an extraction tube into an IRIS.

However, our new integration of the membrane approach from Volkmann et al. (2016) into the stem borehole equilibration method of Marshall et al. (2020) has the advantages of preventing liquid water from entering the membrane (condensation inside the membrane or tubing would still be possible), drying out of the borehole was inhibited since only water vapor (and therefore smaller amounts of water) can pass the membrane pores and fungal or bacterial infections of the tree were prevented due to the very small $(0.2 \mu \mathrm{m})$ pores. The boreholes had an inner diameter of $8-10 \mathrm{~mm}$. Inside the membranes, fine PFAsealed resistance thermometers (HSRTD, Omega Engineering, Norwalk, USA; tolerance: $\pm 0.15^{\circ}-0.35^{\circ} \mathrm{C}$ (over $0^{\circ}-100^{\circ} \mathrm{C}$ ) were installed to measure the borehole temperature. The thermometers logged with the CR800 Data Logger and Multiplexer.

All soil and plant borehole tubes were attached to a bottle filled with desiccant (Drierite W. A. Hammond DRIERITE Co. LTD, Xenia, OH, USA) to dry incoming air at one end and attached to the laser spectrometer (Picarro L2130-i) at the other end of the membrane. The boreholes were further sealed with waterproof glue (ORCA, Aquarium Münster Pahlsmeier GmbH, Telgte, Germany). in situ soil and xylem water was sampled successively for each point, and each sample was measured for 10 $\min$ in total at $\sim 2 \mathrm{~h}$ intervals.

To avoid tube condensation, heating cables (ILLw.CT/Qx, Quintex GmbH, Lauda-Königshofen, Germany) were installed and wrapped with the tube in aluminium foil for insulation. The cables were controlled via an automatic multi socket (Gembird EG-PMS2, Gembird Software Ltd., Almere, The Netherlands) to prevent overheating in summer. To minimise condensation effects, the measurements were checked daily and the system (Manifold with attached tubes and membranes) was flushed for 10 minutes per probe to remove any water (Beyer et al., 2020). In the cases when condensation inside the system was identified the respective data was discarded. We only used daily mean data to exclude sub-daily variance and producing a more reliable dataset, because the focus of our study is on seasonal variability of the willow's behaviour and environment. Daily means were calculated after all corrections and discarding of potential condensation affected data was complete. 


\subsection{Calibration}

Calibration of the in situ soil and xylem water system was achieved by a standard delivery module (Picarro A0101 Standards Delivery Module, Picarro, Inc., Santa Clara, CA, USA) using standards of known isotopic composition in ${ }^{18} \mathrm{O}(-10.41,-7.66$ or $1.45 \%$ ) and ${ }^{2} \mathrm{H}$ ( $72.83,-55.86$ or $16.74 \%$ ), respectively. To correct for isotopic offsets and vapor concentration dependency we used a similar approach to Schmidt et al. (2010) applying a linear regression of vapor concentration dependency slopes for ${ }^{2} \mathrm{H}$ and ${ }^{18} \mathrm{O}$, and of the slopes on the $\delta$-values for ${ }^{2} \mathrm{H}$ and ${ }^{18} \mathrm{O}$ isotopic offset correction. We only used measured water vapor concentrations and added linear regressions of temperature dependency slopes. However, the bulk soil sample results suggested that stronger water concentration dependencies were not fully corrected with this approach, hence, we applied polynomial regressions on measured isotopic compositions for different temperatures. Thus, we were able to correct highly variable water concentrations by using the soil pit temperatures of the specific depths.

To check for $\mathrm{CO}_{2}$ contamination, we used the linewidth variable ('h2o_vy') of the raw data from the Picarro instrument as suggested by Gralher et al. (2016). We found a strong correlation between this variable and the water concentration measured by the laser spectrometer, which indicated that no significant $\mathrm{CO}_{2}$ contamination was detected.

Furthermore, we assumed the liquid water source to be in equilibrium with the measured water vapor allowing us to calculate the liquid-vapor fractionation by a model of type 1 (Majoube, 1971):

$\alpha=\exp \frac{a\left(\frac{10^{6}}{T_{k}^{2}}\right)+b\left(\frac{10^{3}}{T_{k}}\right)+c}{1000}$

where $\alpha$ is the isotopic fractionation factor, $T_{k}$ is the temperature (in $\mathrm{K}$ ), and $a, b$, and $c$ are empirical parameters that vary depending on the isotopologue.

\subsection{Mixing model}

To quantify sources of in situ xylem water from soil water of different depths, we used the Bayesian isotopic mixing model, SIAR (Parnell et al., 2010). Following an initial assessment of potential water sources (see below), the soil isotopes from 10, 40, and $100 \mathrm{~cm}$ from pits A and B were used. These soil depths likely represent the majority of the root distribution of willows due to high near surface rooting densities (Cunniff et al., 2015; Marttila et al., 2017). To establish if the source changes through the growing season, soil and xylem isotopes were divided into weekly bins beginning 21 June 2020, and SIAR was run independently for each weekly group of sources and in situ xylem water. To constrain the mixing model, $\delta^{2} \mathrm{H}, \delta^{18} \mathrm{O}$, and d-excess (d-excess $=\delta^{2} \mathrm{H}-8^{*} \delta^{18} \mathrm{O}$ ) were simultaneously used for the soil and vegetation. To optimize the soil source water to in situ xylem water, Markov Chain Monte Carlo approaches were utilized with 500,000 simulations, using the first 50,000 as burn-in results (which were then discarded). No prior information was provided to the model (uniform a-priori distribution) for each soil depth. For Southern Willow, soil isotopes for each depth were averaged for Pit A and B as the relative similarities between Pit A and B would lead to limited identification of soil source between sites. To evaluate the efficiency of the SIAR model for identifying the proportions of source waters, the mean absolute error (MAE) was evaluated for each weekly bin 


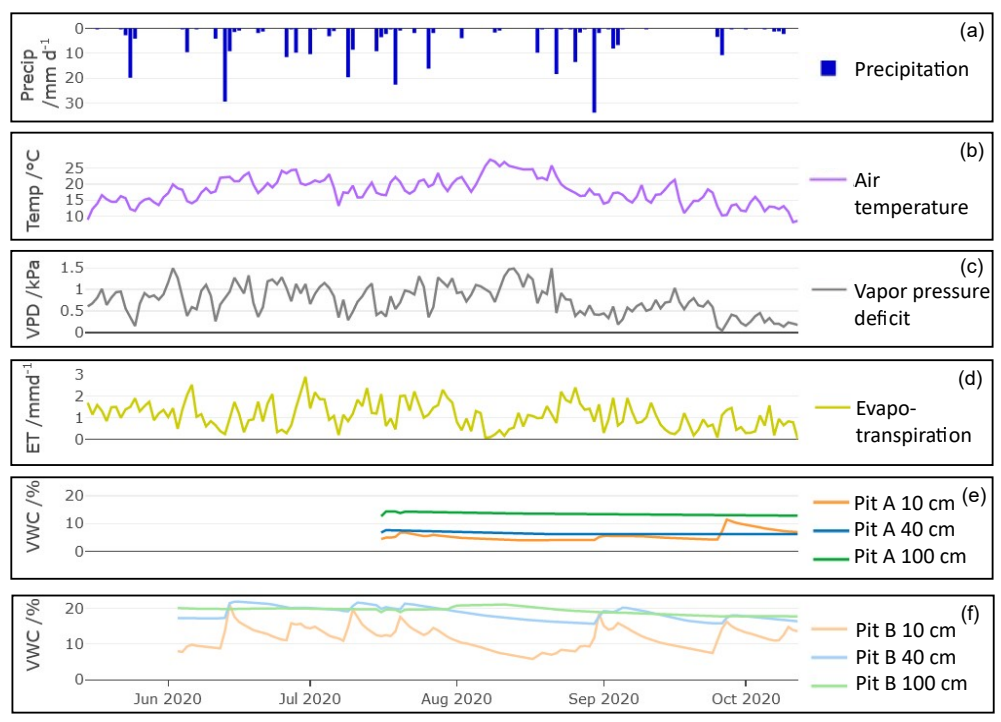

Figure 3. Hydroclimatic conditions showing daily precipitation (a), air temperature (b), vapor pressure deficit (c), evapotranspiration (d), and soil moisture for Pit A (e) and Pit B (f).

using proportion weighted soil isotopes and vegetation isotopes. Proportion weighted soil isotopes were estimated as

$\delta_{\text {mix }}=P 1 * \delta_{10 \mathrm{~cm}}+P 2 * \delta_{40 \mathrm{~cm}}+P 3 * \delta_{100 \mathrm{~cm}}(3)$

where $P 1, P 2$, and $P 3$ are the proportion of water from $10 \mathrm{~cm}, 40 \mathrm{~cm}$, and $100 \mathrm{~cm}$, respectively, as estimated by SIAR.

\section{Results}

\subsection{Hydroclimatic conditions}

The study period was characterised by eleven precipitation events with $>10 \mathrm{~mm} / \mathrm{d}$ (Fig. 3a). The largest event was in late August while the longest dry period occurred in September. Daily mean air temperatures (T) gradually increased until midAugust and decreased afterwards. Vapor pressure deficit (VPD) as a driver of transpiration correlated with T, but also depended on water vapor pressure (high $\mathrm{T}$ and low water vapor pressures causes high VPD). Maxima occurred in the beginning of June and mid-August, in late August the VPD declines alongside T. Evapotranspiration (ET) had minima in times of low precipitation amount and high $\mathrm{T}$, and this was reflected in sap flow rates (Fig. 4). ET increased after large precipitation events when moisture availability increased. At the end of the measuring period, as T and VPD decreased, ET decreased as well.

The volumetric water content (VWC) of the soils at $10 \mathrm{~cm}$ depths strongly responded to precipitation events (Fig. 3e and f). Despite the different time series, it became clear that this variability was more distinct in Pit B (min: 5.7\%, max: 21.0\%, Fig. 3e) than in A (min: 4.0\%, max: 11.4\%, Fig. 3f). Generally, Pit A (beneath the tree canopy) was much drier than B. A precipitation event on 13th June resulted in a significant increase of soil moisture in Pit A, with rapid increases in VMC even 

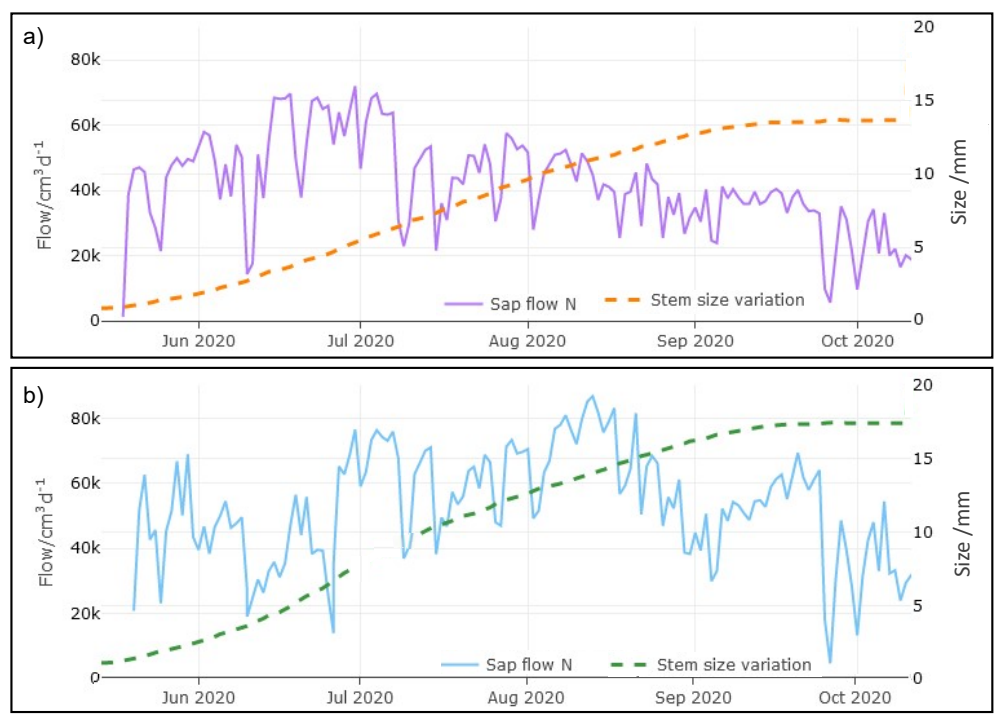

Figure 4. Daily total sap flow measured at the northern sap flow sensor and stem size variation measured for the stem-radius. Plot a) shows the results of Northern Willow and plot b) the ones of Southern Willow.

at $40 \mathrm{~cm}$. VWC responses to precipitation at $100 \mathrm{~cm}$ depth were very damped with little changes detected in both pits (Pit A min: 12.6\%, max: 14.2\%; Pit B min: 17.6\%, max: 20.7\%) even after the August event.

\subsection{Vegetation growth dynamics}

Both trees grew consistently with daily stem-radius incrementation following leaf-out until the end of the growing season at $\sim 15$ September (Fig. 4). The main-growing phase started around June and total growth during the measuring period was 13.6 $\mathrm{mm}$ for Northern Willow and $17.4 \mathrm{~mm}$ for Southern Willow. Daily sap flow ranged from 5000-71000 $\mathrm{cm}^{3} \mathrm{~d}(5-71$ 1/d) for Northern Willow and 4000-86000 $\mathrm{cm}^{3} \mathrm{~d}(4-86$ 1/d) for Southern Willow. This compares well, in terms of order of magnitude for other willows shown to vary between 30 and 1001 per day during the growing season (Schaeffer et al., 2020). Sap flux in Northern Willow increased from the beginning of the measuring period until 30 June after which it dropped. Sap flux in Southern Willow increased until 13 August and then decreased until 4 September followed by an increase until 24 September. Higher ET values (Fig. 3d) were reflected in higher sap flow rates.

\subsection{Dynamics in stable water isotopes}

\subsubsection{General characteristics}

In the dual isotope plot (Fig. 5), all water compartments, except precipitation, mostly lie below the LMWL (local meteoric water line). The largest variability is found in precipitation, while the variability of groundwater and stream water is restricted. 


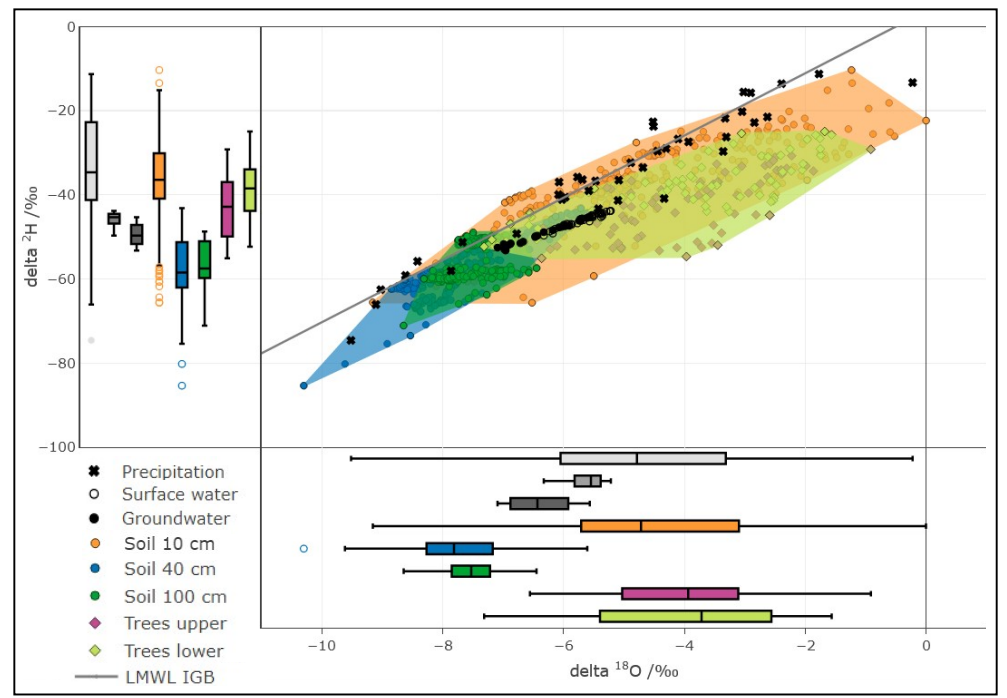

Figure 5. Dual isotope plot of in situ (daily) soil and xylem as well as precipitation (daily), surface and groundwater (weekly) sampling. Soil and tree data are highlighted with boundary polygons for $10 \mathrm{~cm}, 40 \mathrm{~cm}, 100 \mathrm{~cm}$ and tree (upper and lower results joined) clusters. Additional boxplots show the sample distribution of the data sets.

This plot clearly illustrates the substantial overlap between the isotopic compositions of xylem and near-surface soil water measured in situ.

The range of stable isotope values for all measured water compartments (precipitation, soil water, groundwater, lake and stream water) are summarised in Fig. 6 and Table 1. These show more quantitatively the large variability of precipitation, and the very narrow range of stream, lake and groundwater samples $\left(-53.2--42.8 \%\right.$ or $\delta^{2} \mathrm{H}$ and $-7.1--5.2 \%$ for $\left.\delta^{18} \mathrm{O}\right)$. The lc-excess (Fig. 6c) of precipitation varied roughly between -10 and 10\%, while mean values of stream and lake water were $\approx$ $-7 \%$, reflecting the influence of fractionation. Groundwater lc-excess was mostly slightly positive.

\subsubsection{Soil water characteristics}

The uppermost in situ soil water of both Pit A and B was most enriched (up to $-10.4 \%$ for $\delta^{2} \mathrm{H}$ and $0.0 \%$ for $\delta^{18} \mathrm{O}$ ) and showed larger variabilities compared with deeper in situ soil waters (Fig. 6). This was generally similar to the bulk soil water (Fig. S1). The upper in situ soil water of drier Pit A (as Pit A being covered by canopy and closer to the "Canopy Cover" site) was more variable and more enriched than in Pit B. At $100 \mathrm{~cm}$ depth, in situ soil water of both pits showed a very narrow range of isotopic compositions (Table 1) with water from Pit A being roughly $10 \%$ more enriched in $\delta^{2} \mathrm{H}\left(\sim 1 \%\right.$ o in $\left.\delta^{18} \mathrm{O}\right)$ compared to Pit B. Like the bulk soil samples, the in situ results were more depleted in deeper layers (Table 1). The in situ soil water lc-excess of the top layer of the canopy covered Pit A was in general most negative, while water from open spaced Pit B at 10 cm even reached positive lc excess values (Fig. 6). 


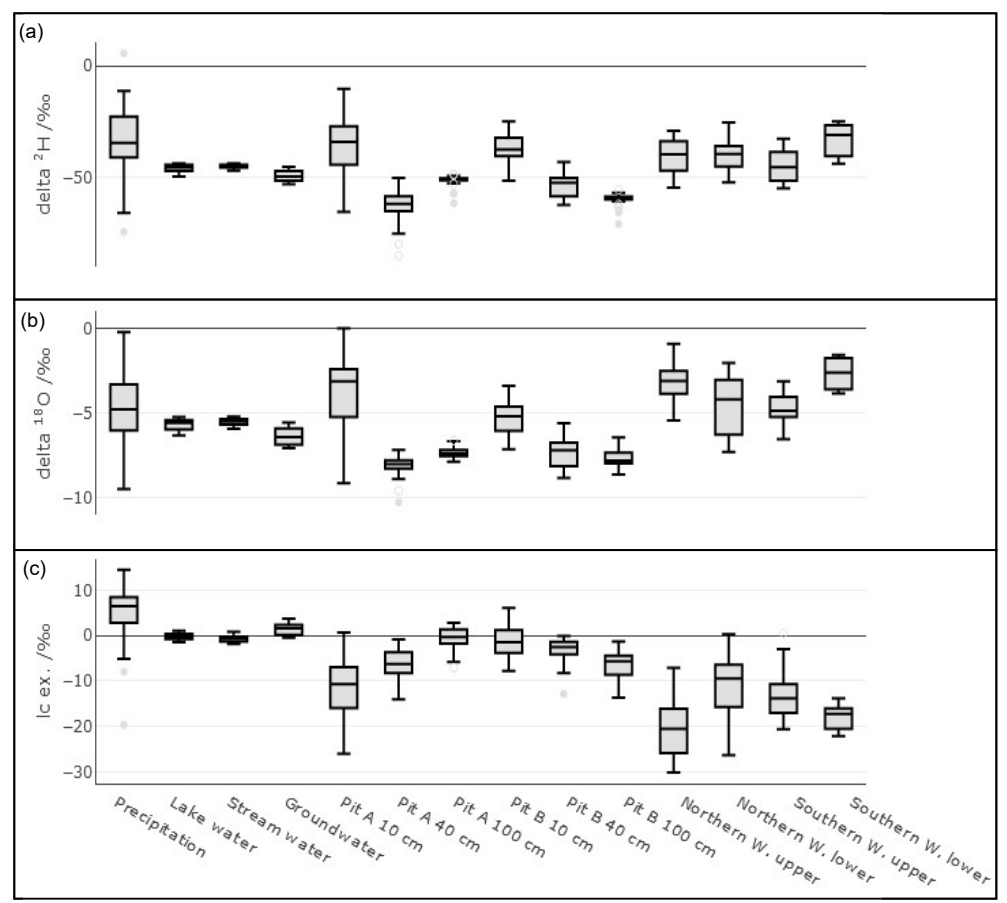

Figure 6. Box plots showing the isotopic composition of daily precipitation sampling, weekly sampled groundwater, lake and stream water, and in situ sampled soil, and xylem water.

Detailed bulk soil water composition is shown in heat maps of $\delta^{18} \mathrm{O}, \delta^{2} \mathrm{H}$ and lc-excess from the "Canopy Covered" (NW of Northern Willow) and "Open Space" (south of Pit B) sample sites (Fig. S2). Both locations showed variation with depth and in time in response to rainfall inputs and changing ET. Usually, the bulk water at $10 \mathrm{~cm}$ was most enriched in $\delta^{18} \mathrm{O}$ and $\delta^{2} \mathrm{H}$, while at 40-70 cm it was most depleted. "Canopy Covered" bulk soil water was, in general, more enriched in $\delta^{18} \mathrm{O}$ than at "Open Space" resulting in differences in lc-excess.

\subsubsection{Xylem water characteristics}

The in situ xylem water showed most similarities with the top soil signatures (Figs. 5 and 6). Like upper in situ soil water, the in situ xylem water varied over wider ranges (e.g., $-29.2--1.9 \%$ for $\delta^{2} \mathrm{H}$ and $-5.4--0.9 \%$ ?: $\delta^{18} \mathrm{O}$ of Northern Willow upper) with their distribution mostly being in the range of the signatures at canopy covered Pit A $10 \mathrm{~cm}$. The in situ xylem water lc-excess values also showed a wide range $(-28--0.2 \%)$, still the values mostly fit inside the total lc-excess range of in situ soil water from Pit A $10 \mathrm{~cm}$.

Cryo-xylem water isotopic composition from the destructive sampling (Figs. S4 and S5) was more depleted compared to the in situ xylem water (Table 1). The lc-excess of the cryo-xylem water was also more enriched compared to the in situ xylem water (Fig. S4). Like the in situ xylem water the cryo-xylem water isotopic composition was comparable to soil $10 \mathrm{~cm}$ isotopic composition, but indicated less evaporated conditions. After correcting the cryo-xylem water $\delta^{2} \mathrm{H}$ data by adding $8.1 \%$ (Chen 
https://doi.org/10.5194/hess-2021-456

Preprint. Discussion started: 22 October 2021

(c) Author(s) 2021. CC BY 4.0 License.

Table 1. The amount (n) and $5^{\text {th }}, 50^{\text {th }}$ (median), and $95^{\text {th }}$ percentiles of $\delta^{18} \mathrm{O}$ and $\delta^{2} \mathrm{H}(\%$ VSMOW) signatures. (Surface water: Lake and Stream water).

\begin{tabular}{|c|c|c|c|c|c|c|c|}
\hline \multirow{2}{*}{ Sample } & \multirow[b]{2}{*}{$\mathrm{n}$} & \multirow[b]{2}{*}{$5^{\text {th }}$ percentile } & \multicolumn{2}{|r|}{$\delta^{2} \mathrm{H} \%$ oVSMOW } & \multicolumn{3}{|c|}{$\delta^{18} \mathrm{O} \%$ oVSMOW } \\
\hline & & & Median & $95^{\text {th }}$ percentile & $5^{\text {th }}$ percentile & Median & $95^{\text {th }}$ percentile \\
\hline Precipitation & 40 & -62.73 & -34.67 & -13.24 & -9.03 & -4.79 & -1.70 \\
\hline Groundwater & 23 & -52.87 & -49.73 & -45.36 & -6.99 & -6.35 & -5.57 \\
\hline Surface water & 40 & -48.75 & -45.34 & -43.90 & -6.18 & -5.62 & -5.24 \\
\hline Soil 10 & 265 & -56.08 & -36.44 & -24.13 & -7.14 & -4.72 & -1.53 \\
\hline Soil 40 & 242 & -66.48 & -58.52 & -45.36 & -8.64 & -7.82 & -6.12 \\
\hline Soil 100 & 261 & -60.49 & -57.60 & -50.21 & -8.12 & -7.53 & -6.89 \\
\hline Canopy covered 10 & 6 & -53.76 & -35.93 & -32.37 & -7.97 & -4.65 & -2.05 \\
\hline Canopy covered 40 & 12 & -62.04 & -53.30 & -43.56 & -8.67 & -7.30 & -5.56 \\
\hline Canopy covered 100 & 12 & -65.44 & -61.82 & -59.03 & -9.04 & -8.42 & -7.95 \\
\hline Open space 10 & 6 & -55.08 & -40.37 & -33.32 & -7.40 & -5.08 & -4.53 \\
\hline Open space 40 & 12 & -61.91 & -52.95 & -42.51 & -8.05 & -6.98 & -5.63 \\
\hline Openspace 100 & 12 & -65.39 & -63.52 & -59.86 & -8.65 & -8.34 & -7.74 \\
\hline Tree upper & 73 & -53.01 & -42.86 & -32.38 & -6.15 & -3.94 & -2.28 \\
\hline Tree lower & 73 & -51.08 & -38.51 & -25.96 & -7.01 & -3.72 & -1.76 \\
\hline Tree cryo & 29 & -63.07 & -55.63 & -46.34 & -7.61 & -5.85 & -4.68 \\
\hline
\end{tabular}

et al., 2020) the cryo-xylem $\delta^{2} \mathrm{H}$ results are more comparable to the in situ ones. However, after this correction the lc-excess values drifted further apart from the in situ xylem water (Fig. S5).

\subsubsection{Temporal dynamics of in situ isotopes}

The daily average of the in situ isotope values showed strong links between larger ( $>10 \mathrm{~mm} / \mathrm{d})$ precipitation events and soil water $\delta^{2} \mathrm{H}$ data (Fig. 7a and b, $\delta^{18} \mathrm{O}$ is shown in Fig. S3). The highest fluctuations occurred in the upper soil layer, while the isotopic composition at 40 and $100 \mathrm{~cm}$ both showed very damped responses to precipitation. At $40 \mathrm{~cm}$ responses were more marked in canopy covered Pit A than Pit B (Figs. 6 and 7).

In contrast, the in situ xylem water composition did not show immediate response to precipitation events, though the shorter run of data makes it difficult to interpret longer-term variations, especially for the Northern Willow. However, the longer time series of the Southern Willow suggests that the xylem composition, like the soil at $10 \mathrm{~cm}$, became more depleted after summer rain in July, before slowly increasing again through August and September (Fig. 7d and e). Comparing the in situ xylem water of the two probes on each tree (upper and lower) they were mostly very similar to one another.

In situ soil water lc-excess was most negative with again higher variability in canopy covered Pit A than in Pit B at a soil depth of $10 \mathrm{~cm}$, (Fig. 8). In Pit A, lc excess exhibited variability that was consistent with cycles of wetting and evaporative 

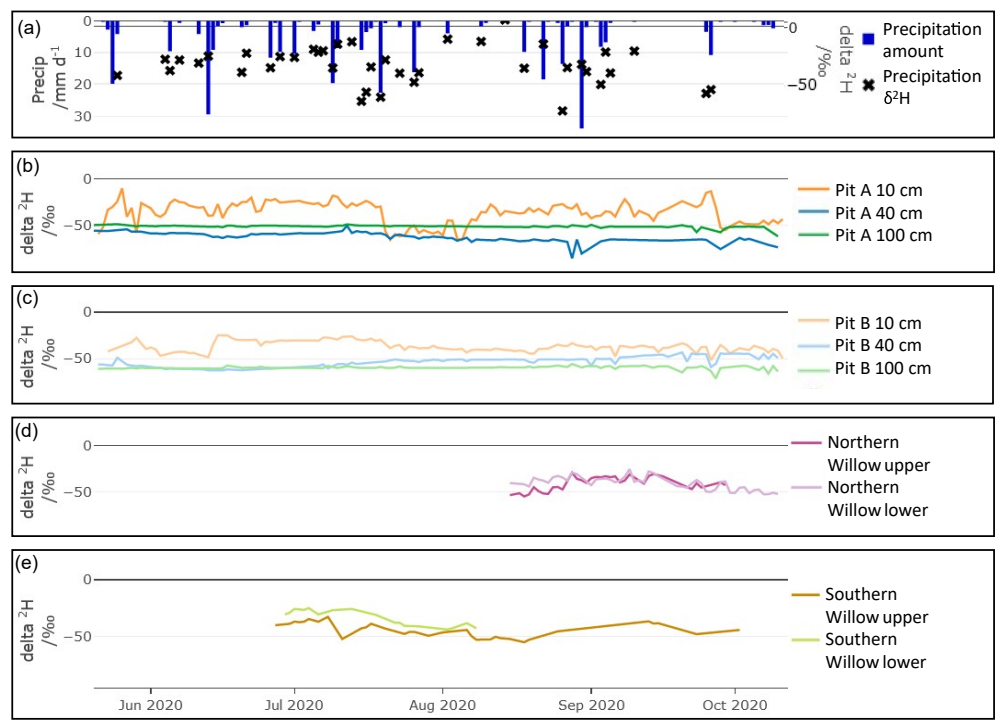

Figure 7. In situ time series of daily ${ }^{2} \mathrm{H}$ in: Precipitation (a), Pit A (b), Pit B (c), Northern Willow (d), and Southern Willow (e).

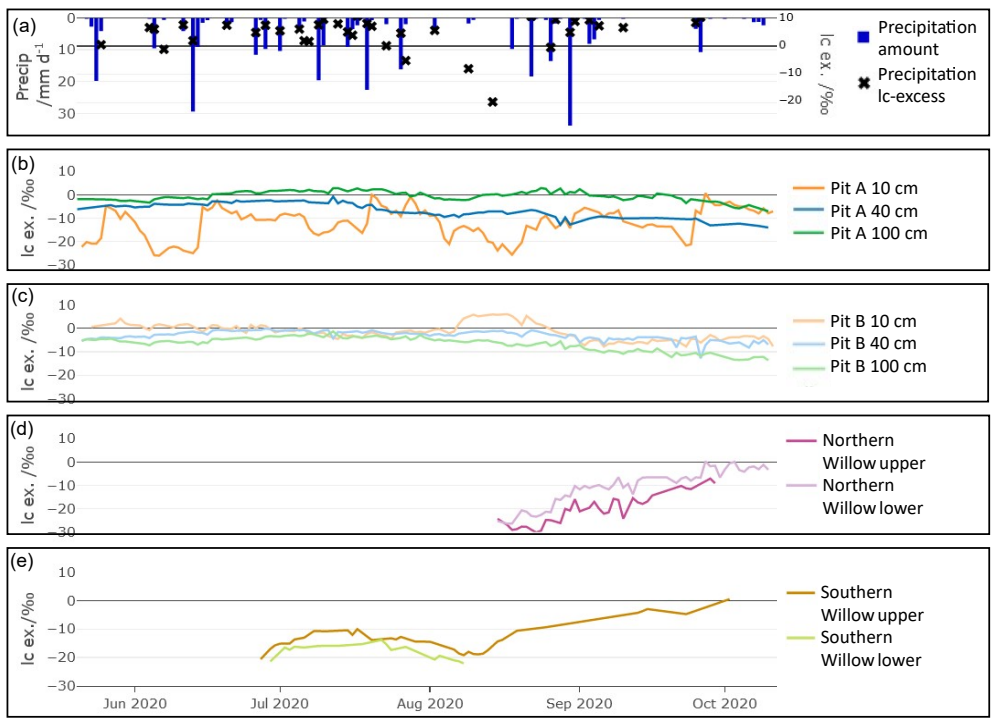

Figure 8. In situ time series of daily lc-excess in: Precipitation (a), Pit A (b), Pit B (c), Northern Willow (d), and Southern Willow (e).

drying causing negative values (Fig. 8b). A similar, though highly damped trend was apparent at $40 \mathrm{~cm}$, while at $100 \mathrm{~cm}$ the $\mathrm{lc}-$ excess remained close to zero, with a suggestion of more fractionated water in the latter part of the study from late September. Variations were more damped in Pit B, and at $10 \mathrm{~cm}$ could become positive following rainfall (Fig. 8c). By late summer, lc-excess at 40 and $100 \mathrm{~cm}$ was gradually becoming more negative, consistent with the percolation of more fractionated water from the upper soil with successive wetting fronts in response to rainfall inputs. 


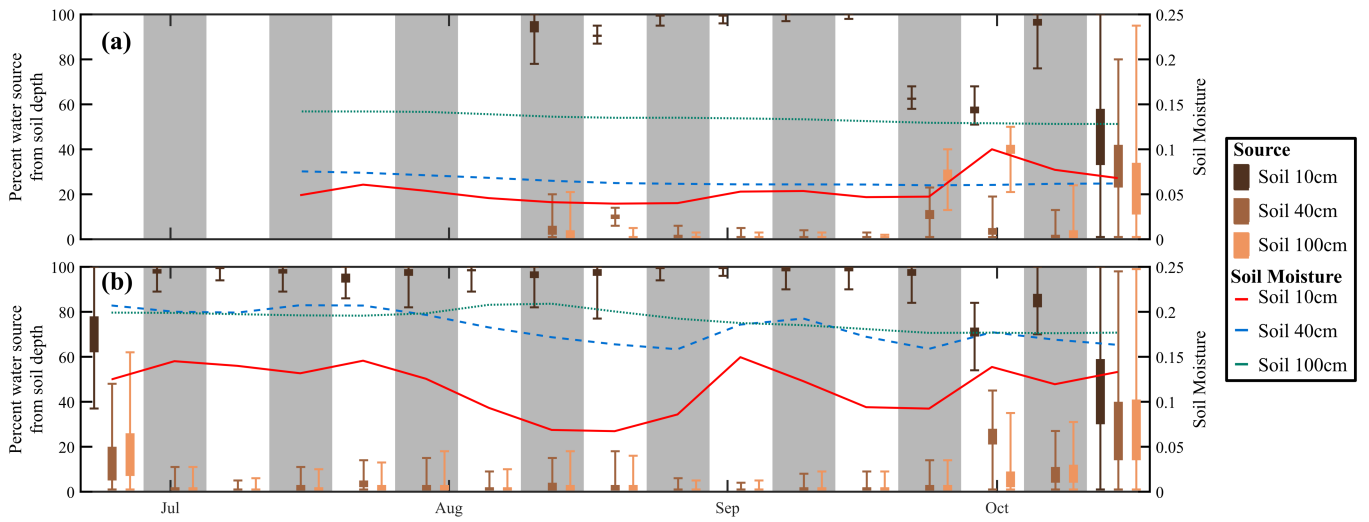

Figure 9. Estimated percentage of willow water from each soil depth in (a) Northern Willow and (b) Southern Willow. The box plots for each source show the $25^{\text {th }}$ and $75^{\text {th }}$ percentiles, with whiskers extending to the minimum and maximum estimated proportion. Gray and white bands show the division of each week. The right-side y-axis shows the soil moisture for each soil depth (weekly average).

In situ xylem water lc-excess in Southern Willow varied around 15\%o until mid-August where the lc-excess increased constantly up to $0.2 \%$. In the Northern Willow, in situ xylem water lc-excess also enriched from the end of August to October.

\subsection{Determining potential xylem water sources}

The SIAR Bayesian mixing model estimated the possible sources of root water uptake (i.e. integrated in the composition of xylem) of the willows from isotope measurements at specific soil water depths (Fig. 9). The mixing model indicated that the xylem composition in both willow trees could be explained by uptake of water almost solely from the top soil $(10 \mathrm{~cm})$ for most of the study period, regardless of soil moisture variations and with low uncertainty (as indicated by the standard deviations in the plot). This is consistent with the qualitative overlap of upper soil water and in situ xylem water in the dual isotope space in Fig. 5. However, at the end of September and in October, there was a suggestion that deeper water sources might have become more important, though results became increasingly uncertain. By this time only $60-95 \%$ could be accounted for by uptake from the top soil, while $0-10 \%$ and $0-40 \%$ were taken from 40 and $100 \mathrm{~cm}$ depth, respectively, in Northern Willow. In Southern Willow, the inferred increased uptake of soil water from 40 and $100 \mathrm{~cm}$ occurred one week later with $\sim 70 \%$ taken from $10 \mathrm{~cm}, \sim 25 \%$ from $40 \mathrm{~cm}$ and $\sim 5 \%$ from $100 \mathrm{~cm}$. Overall mean absolute errors for the prediction of in situ xylem water composition by the SIAR model were small with being $6.5 \%$ and $8.8 \%$ or $\delta^{2} \mathrm{H}$ and 1.8 and $1.3 \%$ o for Southern Willow and Northern Willow respectively (Fig. S6). 


\section{Discussion}

\subsection{Dynamics of sources of root water uptake}

Both qualitative assessment, and quantitative analysis of the isotope data with the Bayesian mixing model, infer that root water uptake by the willows was predominantly sourced from the upper soil horizons during the period when xylem water was analysed in situ. This water tended to be more enriched in heavier isotopes and show the effects of evaporative fractionation. There was nothing to indicate that deeper, more depleted groundwater or stream water sources were a major components of root water uptake during the study period. There was some evidence from the mixing analysis that trees used deeper soil water to supplement shallow sources later in the monitoring period, which coincided with a drier spell in September, though soil moisture availability in the upper soil profile of the pits was not less than earlier in the summer. Although replication was limited, the two soil pits showed marked spatial differences in both soil moisture content and the variability in soil water isotopes, though similar changes with depth were apparent. This likely reflects the effects of interception losses below the tree canopy greatly reducing the moisture content of Pit A. This low storage volume, in turn, results in more marked effects of both evaporative fractionation and mixing of infiltrating rainfall on the soil water isotope signals.

These findings are consistent with other studies that have shown that willows mainly utilise water from the near surface soil horizons (Matilla et al., 2017), which is where nutrient availability is highest (Goldsmith et al., 2012) and most tree species adapt their greatest fine root densities to water and nutrient supply (Hertel et al., 2013). Similarly, Nehemy et al. (2021) found that willows use shallower water sources until drier conditions force water uptake from deeper soil layers. In the current study, it is not clear if the results of the mixing model in September show a similar effect of drier surface soils in September. This shift comes at the end of the growing season, shortly after stem incremental growth ceases, and may be indicative of physiological changes at the onset of autumn. However, it should be noted that the summer of 2020 was not characterised by a prolonged period of water stress, such as the well-documented summer of 2018 (Kleine et al., 2020). Under such conditions a very different water uptake strategy of the willows might be evident, underlining the need for multi-year ecohydrology studies that capture hydroclimatic variability. However, other studies have shown that soils and not groundwater are the most likely sources of root water uptake, even when the latter might be expected (Brooks et al., 2010; Evaristo et al., 2015).

It should be stressed that the mixing model used here is relatively simplistic and coarse as it does not fully characterise the potential heterogeneity in soil properties and root distribution (cf. Sprenger and Allen, 2020). Numerous recent studies show that stem xylem water likely reflects the integrated effects of uptake over many weeks or months, depending on the species, age/size, seasonality and antecedent hydroclimatic variability (e.g. McCutcheon et al., 2017; Tetzlaff et al., 2021; Snelgrove et al., 2021). Moreover, recent modelling work has shown that storage, mixing and re-mobilization of root water uptake in trees may explain lack of direct correlation between soil water and xylem water (Knighton et al., 2020). However, the mixing model likely provides a reasonable first approximation of the willows studied here. It possibly helps that willows have a rapid metabolism, supported by the high sap flow velocities and steady, sustained growth over the study period. Moreover, the two young, same-aged trees on an immature freely-draining soil provided a relatively simple system with more limited variability in the xylem isotope signal between and within the trees than might be expected in a more heterogenous and natural riparian 
forest. More complex ecohydrological modelling that explicitly conceptualises the travel time of water in trees maybe able to provide deeper insights (e.g. Mennekes et al., 2021).

\subsection{Using in situ monitoring over extended periods: potential and challenges}

In situ monitoring is usually characterised by relatively short-term periods (days to weeks) monitoring campaigns, often under controlled experimental conditions (Volkmann et al., 2016; Gaj et al., 2016; Kübert et al., 2020). Such studies were developed to overcome the disadvantages of low frequency destructive sampling in soil and vegetation systems (Beyer et al., 2020; Rothfuss and Javaux, 2017) where a series of methodological uncertainties may affect results (Barbeta et al., 2020; Chen et al. 2020). More recent work has demonstrated the feasibility of field application of spectroscopes in direct in situ monitoring to produce longer-term, reliable data of water in different compartments of the critical zone (Mennekes et al., 2021; Seeger and Weiler, 2021). Our study contributes to this evolution of such isotopic techniques to directly observe ecohydrological processes in soil and vegetation systems. In terms of soil isotope monitoring, our approach was very similar to that of Oerter and Bowen (2017) though we used ambient atmosphere as carrier gas rather than N2. Consequently, we needed to dry the air using Drierite and similar to Volkmann et al. (2016) this allowed us to achieve two hourly sampling with stable plateaus of isotope ratios from each inlet in the system (Fig. 2). Since the interval of root water uptake changes in the willow trees was uncertain, a high temporal resolution was chosen while maintaining a reasonable spatial resolution. As De Deurwaerder et al. (2020) have mentioned the xylem isotopic composition differs over the day and only measuring once a day could imply higher or lower heavy isotope amounts. For seasonal investigations we therefore suggest that fewer sub-daily measurements than we took (but at least 2 or 3 times a day) may be sufficient to capture diurnal variation, but this has to be further tested on other tree species.

The borehole method that we used to sample the xylem water in the trees provided a test of the method proposed by Marshall et al. (2020) in angiosperms. The high frequency results present an improvement on those gained by destructive sampling where questions remain over exactly what is extracted by cryogenic methods (Chen et al., 2020; Barbeta et al., 2020). We observed no off-set in $\delta^{18} \mathrm{O}$ (cf. Volkmann et al., 2016; Marshall et al., 2020) and tests showed no effects of organic or $\mathrm{CO}_{2}$ contamination (Gralher et al., 2016; Beyer et al., 2020). For prolonged installation it seemed advantageous to locate the boreholes further up the tree stem where increment of radial growth is lower as the stem narrows.

A particular challenge for in situ monitoring during the growing season is cooling and keeping the instrument $<35^{\circ} \mathrm{C}$ in high summer temperatures. This was achieved by using a sun shade over the equipment and computer cooling fans. Despite this, the isotope time series for in situ water vapour measured in both soils and xylem showed diurnal variation, which, although reflecting natural processes, did include sampling artifacts that needed to be quality controlled. The soil was most enriched during the day (usually in the mornings) as atmospheric moisture demand increased evaporation. Similarly, xylem water was most enriched during periods of high sap flux during the day, and become depleted overnight. Similar variation has been observed by others (e.g. Martilla et al., 2017, De Deurwaerder et al., 2020). In general, short-term variability in the xylem isotopic composition could be greater than for soils, though longer-term averages were more stable. In the current paper we have not focused on these diurnal variations, as the seasonal changes in root water uptake have been the main focus, and data was averaged on daily time steps. Nevertheless, diurnal cycles of temperature and humidity not only contributed to diurnal 
variation in measurements but also caused condensation in tubing (e.g. Beyer et al., 2020) that could not always be prevented despite heating the tubes (see above). As a result, some data points were rejected but still sufficient data was collected to estimate daily means. This was a particular problem in cooler nights (cf. Gaj et al., 2016) and following rainfall, especially in late summer and autumn as air temperature drops faster compared to soil temperature causing a temperature gradient. The effects were most marked in the top soil layer and xylem where the sampling tubes experienced the most marked temperature variations. For much of the monitoring period flushing the system (Manifold, tubes and probes) with dry air each morning was needed. However, this daily maintenance work is of course highly labour intensive.

In this study we focused on monitoring natural abundance of isotopes in various critical zone compartments, to better understand interactions in the soil-plant-atmosphere continuum of a plot of riparian willow trees. Other studies have reported tracer experiments that focused on specific hypothesis testing under controlled conditions (e.g. Seeger and Weiler, 2021). We see these approaches as being complimentary and our results underline the usefulness of investigating natural abundances of isotopes in critical zone compartments, especially if combined with auxiliary ecohydrological measurements. Although clear tracer "breakthrough" signals are much more evident in labelling studies, there are advantages to observing conditions as they occur in nature and the realistic reaction of trees to its new rain water inputs in relation to the distribution of the water sources.

\section{Conclusions}

We conducted an in situ field study of stable water isotopes in soil water and the xylem of willow trees in conjunction with hydroclimatic monitoring and measurements of sap flow, stem size, soil temperature and moisture, and stable water isotopes in precipitation, lake, stream and groundwater. Our investigation delivered reliable high-frequency stable water isotope data in two soil pits at three depths and two willows in two stem boreholes with a $\sim 2$ hourly resolution over several months (4.5 months in soil and 3 months in trees).

We have shown that the stem borehole approach described by Marshall et al. (2020) successfully worked in the field and in an angiosperm species. Furthermore, we adapted polypropylene membranes inside the stem boreholes which improved our results by reducing the infection risk of the tree and prevented liquid water from the tree to enter the measurement.

The upper soil layer was most variable in moisture content and isotopic composition. Spatial heterogeneity was shown by the two soil pits from which one was located under the canopy while the other one was in the open. The canopy covered soil pit had lower volumetric water contents, but more enriched and more variable isotopic composition than the one in open space.

The xylem isotopic composition mostly resembled top soil water and mixing models indicated that this water source could explain $\sim 90 \%$ of root water uptake. The summer sap flux velocity remained suggesting rapid travel times of a few days and showed no obvious response to lower soil water conditions (i.e. reduction) or precipitation events (i.e. increase). At the end of the season, the reliance on upper soil water uptake reduced (but was still $\sim 60 \%$ ) suggesting use of additional deeper soil waters. It is likely that the willow trees preferred top soil water in summer due to nutrient supply while at the end of their growing period they shifted to layers with higher soil water content. 
https://doi.org/10.5194/hess-2021-456

Preprint. Discussion started: 22 October 2021

(c) Author(s) 2021. CC BY 4.0 License.

(c) (1)

Although our approach delivered novel and reliable data, improvements in terms of set up and choosing locations or time periods with more variable water source availability will benefit further investigations. For long-term in situ xylem water investigations further research tackling challenges such as night-time tube condensation, compression of the membrane and testing on different tree species is required.

Data availability. The isotope data are uploaded and available with a password (to be received from the corresponding author upon request) into the open access data base FRED at IGB.

Author contributions. The study was designed by JL, DT, MD, CS. Fieldwork and data collection were undertaken by JL, DD. Data were analysed by JL, with ongoing discussion and inputs from DT, CS, MD, AS. JL prepared the draft manuscript, which subsequently all authors contributed to and edited.

Competing interests. The authors declare that they have no conflict of interest.

Acknowledgements. We acknowledge the BMBF (funding code 033W034A) as well as the Open Access Publication Fund by IGB and the Leibniz Association's Open Access Publishing Fund. The authors are grateful to Jonas Freymüller, Hauke Dämpfling, and Adrian Dahlmann who were involved in the in situ site setup and maintenance. We also thank Lukas Kleine and Christian Marx for their help in soil and twig sampling and characterisation as well as Christian Marx for cryogenic extraction of the twig samples. Chris Soulsby's contributions were supported by the Leverhulme Trust ISOLAND project (RPG-2018-375). 


\section{References}

Barbeta, A., Peñuelas, J.: Relative contribution of groundwater to plant transpiration estimated with stable isotopes. Scientific reports, 7(1), 1-10, https://doi.org/10.1038/s41598-017-09643-x, 2017.

Barbeta, A., Gimeno, T. E., Clavé, L., Fréjaville, B., Jones, S. P., Delvigne, C., Wingate, L., Ogée, J.: An explanation for the isotopic offset between soil and stem water in a temperate tree species. New Phytologist, 227(3), 766-779, https://doi.org/10.1111/nph.16564, 2020.

Berry, Z. C., Evaristo, J., Moore, G., Poca, M., Steppe, K., Verrot, L., Asbjornsen, H., Borma, L. S., Bretfeld, M., Hervé-Fernández, P., Seyfried, M., Schwendenmann, L., Sinacore, K., De Wispelaere, L., McDonnell, J.: The two water worlds hypothesis: Addressing multiple working hypotheses and proposing a way forward, Ecohydrology, 11(3), e1843, https://doi.org/10.1002/eco.1843, 2018.

Beyer, M., Hamutoko, J. T., Wanke, H., Gaj, M., Koeniger, P.: Examination of deep root water uptake using anomalies of soil water stable isotopes, depth-controlled isotopic labeling and mixing models, Journal of Hydrology, 566, 122-136, https://doi.org/10.1016/j.jhydrol. 2018.08.060., 2018.

Beyer, M., Kühnhammer, K., Dubbert, M.: In situ measurements of soil and plant water isotopes: a review of approaches, practical considerations and a vision for the future, Hydrology and Earth System Sciences, 24(9), 4413-4440, https://doi.org/10.5194/hess-24-4413-2020, 2020.

Braden-Behrens, J., Markwitz, C., Knohl, A.: Eddy covariance measurements of the dual-isotope composition of evapotranspiration, Agricultural and Forest Meteorology, 269, 203-219, https://doi.org/10.1016/j.agrformet.2019.01.035, 2019.

Brinkmann, N., Eugster, W., Zweifel, R., Buchmann, N., Kahmen, A.: Temperate tree species show identical response in tree water deficit but different sensitivities in sap flow to summer soil drying, Tree Physiology, 36(12), 1508-1519, https://doi.org/10.1111/nph.15255, 2016.

Brooks, J. R., Barnard, H. R., Coulombe, R., McDonnell, J. J.: Ecohydrologic separation of water between trees and streams in a Mediterranean climate, Nature Geoscience, 3(2), 100-104, https://doi.org/10.1038/NGEO722, 2010.

Burba, G.: Eddy covariance method for scientific, industrial, agricultural and regulatory applications: A field book on measuring ecosystem gas exchange and areal emission rates, LI-COR Biosciences, Nebraska, USA, 2013.

Burgess, S. S., Adams, M. A., Turner, N. C., Beverly, C. R., Ong, C. K., Khan, A. A., Bleby, T. M.: An improved heat pulse method to measure low and reverse rates of sap flow in woody plants, Tree physiology, 21(9), 589-598, https://doi.org/10.1093/treephys/21.9.589, 2001.

Butz, P., Hölscher, D., Cueva, E., Graefe, S.: Tree water use patterns as influenced by phenology in a dry forest of Southern Ecuador, Frontiers in plant science, 9, 945, https://doi.org/10.3389/fpls.2018.00945, 2018.

Chen, Y., Helliker, B. R., Tang, X., Li, F., Zhou, Y., Song, X.: Stem water cryogenic extraction biases estimation in deuterium isotope composition of plant source water, Proceedings of the National Academy of Sciences, 117(52), 33345-33350, www.pnas.org/cgi/doi/10. 1073/pnas.2014422117, 2020.

Cunniff, J., Purdy, S. J., Barraclough, T. J., Castle, M., Maddison, A. L., Jones, L. E., Shield, I. F., Gregory, A. S., Karp, A.: High yielding biomass genotypes of willow (Salix spp.) show differences in below ground biomass allocation, Biomass and Bioenergy, 80, 114-127, http://dx.doi.org/10.1016/j.biombioe.2015.04.020, 2015.

Dawson, T. E., Ehleringer, J. R.: Streamside trees that do not use stream water, Nature, 350(6316), 335-337, https://www.nature.com/articles/ $350335 \mathrm{a} 0,1991$. 
De Deurwaerder, H., Visser, M. D., Detto, M., Boeckx, P., Meunier, F., Kuehnhammer, K., Magh, R.-K., Marshall, J. D., Wang, L., Zhao, L., Verbeeck, H.: Causes and consequences of pronounced variation in the isotope composition of plant xylem water, Biogeosciences, 17(19), 4853-4870, https://doi.org/10.5194/bg-17-4853-2020, 2020.

Deutsche Stratigraphische Kommission (Hrsg.; Redaktion, Koordination und Gestaltung: Menning, M., Hendrich, A.): Stratigraphische Tabelle von Deutschland 2016, Potsdam (GeoForschungsZentrum), (1) Tafel plan 100 x $141 \mathrm{~cm}$, (2) Tafel gefaltet A4, 2016.

Deutscher Wetterdienst (DWD): https://www.dwd.de/DE/leistungen/klimadatendeutschland/vielj_mittelwerte.html, last access: 16 November 2020a

Deutscher Wetterdienst (DWD): https://opendata.dwd.de/climate_environment/CDC/observations_germany/climate/daily/momo_precip/ recenr/, last access: 16 November $2020 \mathrm{~b}$

Driescher, E., Behrendt, H., Schellenberger, G., Stellmacher, R.: Lake Müggelsee and its environment—natural conditions and anthropogenic impacts. Internationale Revue der gesamten Hydrobiologie und Hydrographie, 78(3), 327-343, 1993.

Dubbert, M., Piayda, A., Cuntz, M., Correia, A. C., Costa e Silva, F., Pereira, J. S., Werner, C.: Stable oxygen isotope and flux partitioning demonstrates understory of an oak savanna contributes up to half of ecosystem carbon and water exchange, Frontiers in plant science, 5 , 530, https://doi.org/10.3389/fpls.2014.00530, 2014

Ehleringer, J. R., Dawson, T. E.: Water uptake by plants: perspectives from stable isotope composition, Plant, cell \& environment, 15(9), 1073-1082, https://doi.org/10.1111/j.1365-3040.1992.tb01657.x, 1992.

Evaristo, J., Jasechko, S., McDonnell, J. J.: Global separation of plant transpiration from groundwater and streamflow, Nature, 525(7567), 91-94, https://doi.org/10.1038/nature14983, 2015.

Friesen, J., Van Stan, J. T.: Early European observations of precipitation partitioning by vegetation: a synthesis and evaluation of 19th century findings, Geosciences, 9(10), 423, https://doi.org/10.3390/geosciences9100423, 2019.

Gaj, M., Beyer, M., Koeniger, P., Wanke, H., Hamutoko, J., Himmelsbach, T.: In situ unsaturated zone water stable isotope (2 H and $18 \mathrm{O})$ measurements in semi-arid environments: a soil water balance, Hydrology and Earth System Sciences, 20(2), 715-731, https://doi.org/10.5194/hess-20-715-2016, 2016.

Goldsmith, G. R., Muñoz-Villers, L. E., Holwerda, F., McDonnell, J. J., Asbjornsen, H., Dawson, T. E.: Stable isotopes reveal linkages among ecohydrological processes in a seasonally dry tropical montane cloud forest, Ecohydrology, 5(6), 779-790, https://doi.org/10.1002/eco.268, 2012.

Goldsmith, G. R., Allen, S. T., Braun, S., Engbersen, N., González-Quijano, C. R., Kirchner, J. W., Siegwolf, R. T.: Spatial variation in throughfall, soil, and plant water isotopes in a temperate forest, Ecohydrology, 12(2), e2059, https://doi.org/10.1002/eco.2059, 2019.

Gralher, B., Herbstritt, B., Weiler, M., Wassenaar, L. I., Stumpp, C.: Correcting laser-based water stable isotope readings biased by carrier gas changes, Environmental science \& technology, 50(13), 7074-7081, https://doi.org/10.1021/acs.est.6b01124, 2016.

Herbstritt, B., Gralher, B., Weiler, M.: Continuous in situ measurements of stable isotopes in liquid water, Water Resources Research, 48(3), https://doi.org/10.1029/2011WR011369, 2012.

550 Hertel, D., Strecker, T., Müller-Haubold, H., Leuschner, C.: Fine root biomass and dynamics in beech forests across a precipitation gradient-is optimal resource partitioning theory applicable to water-limited mature trees?, Journal of Ecology, 101(5), 1183-1200, https://doi.org/10.1111/1365-2745.12124, 2013.

IAEA/GNIP: Precipitation sampling guide V2.02, September 2014

Jackson, P. C., Cavelier, J., Goldstein, G., Meinzer, F. C., Holbrook, N. M.: Partitioning of water resources among plants of a lowland tropical forest, Oecologia, 101(2), 197-203, https://www.jstor.org/stable/4220873, 1995. 
Jasechko, S., Sharp, Z. D., Gibson, J. J., Birks, S. J., Yi, Y., Fawcett, P. J.: Terrestrial water fluxes dominated by transpiration, Nature, 496(7445), 347-350, https://doi.org/10.1038/nature11983, 2013.

Joshi, R., Wani, S. H., Singh, B., Bohra, A., Dar, Z. A., Lone, A. A., Pareek, A., Singla-Pareek, S. L.: Transcription factors and plants response to drought stress: current understanding and future directions, Frontiers in Plant Science, 7, 1029, https://doi.org/10.3389/fpls.2016.01029, 2016.

Kleine, L., Tetzlaff, D., Smith, A., Wang, H., Soulsby, C.: Using water stable isotopes to understand evaporation, moisture stress, and rewetting in catchment forest and grassland soils of the summer drought of 2018, Hydrology and Earth System Sciences, 24(7), 3737-3752, https://doi.org/10.5194/hess-24-3737-2020, 2020.

Knighton, J., Kuppel, S., Smith, A., Soulsby, C., Sprenger, M., Tetzlaff, D.: Using isotopes to incorporate tree water storage and mixing dynamics into a distributed ecohydrologic modelling framework, Ecohydrology, 13(3), e2201, https://doi.org/10.1002/eco.2201, 2020.

Koeniger, P., Marshall, J. D., Link, T., Mulch, A.: An inexpensive, fast, and reliable method for vacuum extraction of soil and plant water for stable isotope analyses by mass spectrometry, Rapid Communications in Mass Spectrometry, 25(20), 3041-3048, https://doi.org/10.1002/rcm.5198, 2011.

Kozii, N., Haahti, K., Tor-ngern, P., Chi, J., Hasselquist, E. M., Laudon, H., Launiainen, S., Oren, R., Peichl, M., Wallerman, J., Hasselquist, N. J.: Partitioning growing season water balance within a forested boreal catchment using sap flux, eddy covariance, and a process-based model, Hydrology and Earth System Sciences, 24(6), 2999-3014, https://doi.org/10.5194/hess-24-2999-2020, 2020.

Kübert, A., Paulus, S., Dahlmann, A., Werner, C., Rothfuss, Y., Orlowski, N., Dubbert, M.: Water stable isotopes in ecohydrological field research: Comparison between in situ and destructive monitoring methods to determine soil water isotopic signatures, Frontiers in plant science, 11, 387, https://doi.org/10.3389/fpls.2020.00387, 2020.

Kühnhammer, K., Kübert, A., Brüggemann, N., Deseano Diaz, P., van Dusschoten, D., Javaux, M., Merz, S., Vereecken, H., Dubbert, M., Rothfuss, Y.: Investigating the root plasticity response of Centaurea jacea to soil water availability changes from isotopic analysis, New Phytologist, 226(1), 98-110, https://doi.org/10.1111/nph.16352, 2020.

Majoube, M.: Fractionnement en oxygène 18 et en deutérium entre l'eau et sa vapeur, Journal de Chimie Physique, 68, $1423-1436,1971$.

Marshall, D. C.: Measurement of sap flow in conifers by heat transport, Plant physiology, 33(6), 385, 1958.

Marshall, J. D., Cuntz, M., Beyer, M., Dubbert, M., Kuehnhammer, K.: Borehole equilibration: testing a new method to monitor the isotopic composition of tree xylem water in situ, Frontiers in plant science, 11, 358, https://doi.org/10.3389/fpls.2020.00358, 2020.

Martín-Gómez, P., Barbeta, A., Voltas, J., Peñuelas, J., Dennis, K., Palacio, S., Dawson, T. E., Ferrio, J. P.: Isotope-ratio infrared spectroscopy: a reliable tool for the investigation of plant-water sources?, New Phytologist, 207(3), 914-927, https://doi.org/10.1111/nph.13376, 2015.

Marttila, H., Dudley, B. D., Graham, S., Srinivasan, M. S.: Does transpiration from invasive stream side willows dominate low-flow conditions? An investigation using hydrometric and isotopic methods in a headwater catchment, Ecohydrology, 11(2), e1930, https: //doi.org/10.1002/eco.1930, 2017.

McCutcheon, R. J., McNamara, J. P., Kohn, M. J., Evans, S. L.: An evaluation of the ecohydrological separation hypothesis in a semiarid catchment, Hydrological processes, 31(4), 783-799, https://doi.org/10.1002/hyp.11052, 2017.

McDonnell, J. J., McGuire, K., Aggarwal, P., Beven, K. J., Biondi, D., Destouni, G., Dunn, S., James, A., Kirchner, J., Kraft, P., Lyon, S., Maloszewski, P., Newman, B., Pfister, L., Rinaldo, A., Rodhe, A., Sayama, T., Seibert, J., Solomon, K., Soulsby, C., Stewart, M., Tetzlaff, D., Tobin, C., Troch, P., Weiler, M., Western, A., Wörman, A., Wrede, S.: How old is streamwater? Open questions in catchment transit time conceptualization, modeling and analysis, Hydrological Processes, 24, 1745-1754, https://doi.org/10.1002/wat2.1027, 2010. 
Mencuccini, M., Hölttä, T., Sevanto, S., Nikinmaa, E. (2013). Concurrent measurements of change in the bark and xylem diameters of trees reveal a phloem-generated turgor signal. New phytologist, 198(4), 1143-1154.Mennekes, D., Rinderer, M., Seeger, S., Orlowski, N.: Ecohydrological travel times derived from in situ stable water isotope measurements in trees during a semi-controlled pot experiment, Hydrology and Earth System Sciences Discussions, 1-34, https://doi.org/10.1111/nph.12224, 2021.

Mennekes, D., Rinderer, M., Seeger, S., Orlowski, N.: Ecohydrological travel times derived from in situ stable water isotope measurements in trees during a semi-controlled pot experiment, Hydrology and Earth System Sciences Discussions, 1-34, https://doi.org/10.5194/ hess-2020-674, 2021.

Nehemy, M. F., Benettin, P., Asadollahi, M., Pratt, D., Rinaldo, A., McDonnell, J. J.: Tree water deficit and dynamic source water partitioning, Hydrological Processes, 35(1), e14004, https://doi.org/10.1002/hyp.14004, 2021.

Oerter, E. J., Bowen, G.: In situ monitoring of $\mathrm{H}$ and $\mathrm{O}$ stable isotopes in soil water reveals ecohydrologic dynamics in managed soil systems, Ecohydrology, 10(4), e1841, https://doi.org/10.1002/eco.1841, 2017.

OpenStreetMap contributors, www.openstreetmap.org/copyright, last access: 20. June 2020

Orlowski, N., Breuer, L., McDonnell, J. J.: Critical issues with cryogenic extraction of soil water for stable isotope analysis, Ecohydrology, 9(1), 1-5, https://doi.org/10.1002/eco.1722, 2016.

Paloschi, R. A., Ramos, D. M., Ventura, D. J., Souza, R., Souza, E., Morellato, L. P. C., Nóbrega, R. L. B., Coutinho, Í., A., C., Verhoef, A., Körting, T. S., Borma, L. D. S.: Environmental Drivers of Water Use for Caatinga Woody Plant Species: Combining Remote Sensing Phenology and Sap Flow Measurements, Remote Sensing, 13(1), 75, https://doi.org/10.3390/rs13010075, 2021.

Parnell, A. C., Inger, R., Bearhop, S., Jackson, A. L.: Source partitioning using stable isotopes: coping with too much variation, PloS one, 5(3), e9672, https://doi.org/10.1371/journal.pone.0009672, 2010.

Phillips, D. L., Gregg, J. W.: Source partitioning using stable isotopes: coping with too many sources, Oecologia, 136(2), 261-269, https://doi.org/10.1007/s00442-003-1218-3, 2003.

Rossiter, D. G.: Classification of urban and industrial soils in the world reference base for soil resources (5 pp), Journal of Soils and Sediments, 7(2), 96-100, http://dx.doi.org/10.1065/jss2007.02.208, 2007.

Rothfuss, Y., Biron, P., Braud, I., Canale, L., Durand, J. L., Gaudet, J. P., Richard, P., Vauclin, M., Bariac, T.: Partitioning evapotranspiration fluxes into soil evaporation and plant transpiration using water stable isotopes under controlled conditions, Hydrological processes, 24(22), 3177-3194, https://doi.org/10.1002/hyp.7743, 2010.

Rothfuss, Y., Vereecken, H., Brüggemann, N.: Monitoring water stable isotopic composition in soils using gas-permeable tubing and infrared laser absorption spectroscopy, Water resources research, 49(6), 3747-3755, https://doi.org/10.1002/wrcr.20311, 2013.

Rothfuss, Y., Javaux, M.: Reviews and syntheses: Isotopic approaches to quantify root water uptake: a review and comparison of methods, Biogeosciences, 14(8), 2199-2224, https://doi.org/10.5194/bg-14-2199-2017, 2017.

Schaeffer, S. M., Williams, D. G., Goodrich, D. C.: Transpiration of cottonwood/willow forest estimated from sap flux, Agricultural and Forest Meteorology, 105(1-3), 257-270, https://doi.org/10.1016/S0168-1923(00)00186-6, 2000.

Schmidt, M., Maseyk, K., Lett, C., Biron, P., Richard, P., Bariac, T., Seibt, U.: Concentration effects on laser-based $\delta^{18} \mathrm{O}$ and $\delta^{2} \mathrm{H}$ measurements and implications for the calibration of vapour measurements with liquid standards, Rapid Communications in Mass Spectrometry, 24(24), 3553-3561, https://doi.org/10.1002/rcm.4813, 2010.

Seeger, S., Weiler, M.: Temporal dynamics of tree xylem water isotopes: in situ monitoring and modelling, Biogeosciences Discussions, 1-41, https://doi.org/10.5194/bg-2021-35, 2021. 
Snelgrove, J. R., Buttle, J. M., Kohn, M. J., Tetzlaff, D.: Co-evolution of xylem water and soil water stable isotopic composition in a northern mixed forest biome, Hydrology and Earth System Sciences, 25(4), 2169-2186, https://doi.org/10.5194/hess-25-2169-2021, 2021.

Sohel, M. S. I., Grau, A. V., McDonnell, J. J., Herbohn, J.: Tropical forest water source patterns revealed by stable isotopes: A preliminary analysis of 46 neighboring species, Forest Ecology and Management, 494, 119355, https://doi.org/10.1016/j.foreco.2021.119355, 2021.

Sprenger, M., Stumpp, C., Weiler, M., Aeschbach, W., Allen, S. T., Benettin, P., Dubbert, M., Hartmann, A., Hrachowitz, M., Kirchner, J. W., McDonnell, J. J., Orlowski, N., Penna, D., Pfahl, S., Rinderer, M., Rodriguez, N., Schmidt, M., Werner, C.: The demographics of water: A review of water ages in the critical zone. Reviews of Geophysics, 57(3), 800-834, https://doi.org/ 10.1029/2018RG000633, 2019.

Sprenger, M., Allen, S. T.: What ecohydrologic separation is and where we can go with it, Water Resources Research, 56(7), e2020WR027238, https://doi.org/10.1029/2020WR027238, 2020.

Stock, B. C., Jackson, A. L., Ward, E. J., Parnell, A. C., Phillips, D. L., Semmens, B. X.: Analyzing mixing systems using a new generation of Bayesian tracer mixing models, PeerJ, 6, e5096, https://doi.org/10.7717/peerj.5096, 2018.

Süßel, F., Brüggemann, W.: Tree water relations of mature oaks in southwest Germany under extreme drought stress in summer 2018, Plant Stress, 1, 100010, https://doi.org/https://doi.org/10.1016/j.stress.2021.100010, 2021.

Tetzlaff, D., Buttle, J., Carey, S. K., Kohn, M. J., Laudon, H., McNamara, J. P., Smith, A., Sprenger, M., Soulsby, C.: Stable isotopes of water reveal differences in plant-soil water relationships across northern environments, Hydrological Processes, 35(1), e14023, https://doi.org/10.1002/hyp.14023, 2021.

Thompson, S. E., Harman, C. J., Heine, P., Katul, G. G.: Vegetation-infiltration relationships across climatic and soil type gradients, Journal of Geophysical Research, 115(G2), https://doi.org/10.1029/2009JG001134, 2010.

Volkmann, T. H., Weiler, M.: Continual in situ monitoring of pore water stable isotopes in the subsurface, Hydrology and Earth System Sciences, 18(5), 1819-1833, https://doi.org/10.5194/hess-18-1819-2014, 2014.

650 Volkmann, T. H., Kühnhammer, K., Herbstritt, B., Gessler, A., Weiler, M.: A method for in situ monitoring of the isotope composition of tree xylem water using laser spectroscopy, Plant, Cell \& Environment, 39(9), 2055-2063, https://doi.org/10.1111/pce.12725, 2016.

von Freyberg, J., Allen, S. T., Grossiord, C., Dawson, T. E.: Plant and root-zone water isotopes are difficult to measure, explain, and predict: Some practical recommendations for determining plant water sources, Methods in Ecology and Evolution, 11(11), 1352-1367, https://doi.org/10.1111/2041-210X.13461, 2020.

Wassenaar, L. I., Hendry, M. J., Chostner, V. L., Lis, G. P.: High resolution pore water $\delta^{2} \mathrm{H}$ and $\delta^{18} \mathrm{O}$ measurements by $\mathrm{H} 2 \mathrm{O}$ (liquid)- H2O (vapor) equilibration laser spectroscopy, Environmental science \& technology, 42(24), 9262-9267, https://doi.org/10.1021/es802065s, 2008.

West, A. G., Patrickson, S. J., Ehleringer, J. R.: Water extraction times for plant and soil materials used in stable isotope analysis, Rapid Communications in Mass Spectrometry, 20(8), 1317-1321, https://doi.org/10.1002/rcm.2456, 2006.

Williams, D. G., Cable, W., Hultine, K., Hoedjes, J. C. B., Yepez, E. A., Simonneaux, V., Er-Raki, S., Boulet, G., de Bruin, H. A. R., Chehbouni, A., Hartogensis, O. K., Timouk, F.: Evapotranspiration components determined by stable isotope, sap flow and eddy covariance techniques, Agricultural and Forest Meteorology, 125(3-4), 241-258, https://doi.org/10.1016/j.agrformet.2004.04.008, 2004.

Yang, B., Wen, X., Sun, X.: Seasonal variations in depth of water uptake for a subtropical coniferous plantation subjected to drought in an East Asian monsoon region, Agricultural and Forest Meteorology, 201, 218-228, http://dx.doi.org/10.1016/j.agrformet.2014.11.020, 2015.

Zweifel, R., Zimmermann, L., Newbery, D. M.: Modeling tree water deficit from microclimate: an approach to quantifying drought stress, Tree physiology, 25(2), 147-156, https://doi.org/https://doi.org/10.1093/treephys/25.2.147, 2005. 
https://doi.org/10.5194/hess-2021-456

Preprint. Discussion started: 22 October 2021

(C) Author(s) 2021. CC BY 4.0 License.

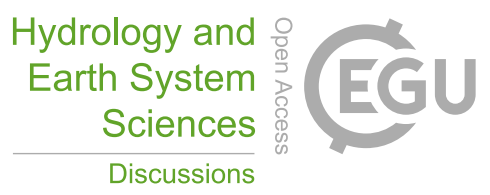

Zweifel, R.: Radial stem variations-a source of tree physiological information not fully exploited yet, Plant, Cell \& Environment, 39(2), 231-232, https://doi.org/10.1111/pce.12613, 2016. 